\title{
Effects of Nano-sized Titanium Powder on the Anti-corrosion Property of Epoxy Coatings on Steel
}

DOI: $10.15255 /$ KUI.2013.026 KUI-20/2014

Original scientific paper

Received August 17, 2013

Accepted November 7, 2013

\author{
X. Z. Zhang* and Y. J. Li \\ Taiyuan University of Science \& Technology, 030024 Taiyuan, PR China
}

\begin{abstract}
The protective performance of epoxy asphalt coatings modified by 200 meshes titanium powder, in mass fractions $2 \%, 5 \%, 10 \%$, and $20 \%$, and coatings without titanium and with mass fractions of nano-sized titanium powder $5 \%, 10 \%$, and $20 \%$, was studied using electrochemical impedance spectroscopy (EIS) and salt spray test. Moreover, infrared spectrum and X-ray photoelectron spectroscopy (XPS) were used to study the structure of the coatings.

The results show that nanometer titanium may be involved in the reaction solidification process of the coatings. Therefore, the addition of titanium nano-powder to the coatings does not significantly change the physical properties of the coatings (toughness). On the other hand, coatings with nano-sized titanium powder have better protection performance than coatings containing micrometre-sized titanium powder. At the same time, because a chemical key exists between nano-sized titanium particles and the coating agent, the increase in the number of charge carriers in the coating due to the existence of the titanium metal is lower. For this reason, the resistance change order is different from the change law of the coating modified with the micrometre-sized titanium powder, and the change rule of the electrical resistance for the coatings modified by nano-powder titanium cannot be explained by the change of dielectric constants.
\end{abstract}

Key words: Anti-corrosion property, nano-sized titanium, epoxy coal tar coating

\section{Introduction}

Because of the existence of corrosion media such as chlorine, serious corrosion attacks ships, offshore and marine structure. Scholars worldwide have been long committed to the research of marine corrosion and development of anti-corrosion agents, and have achieved remarkable results. But so far, the conventional ocean coating inevitably makes microholes or microcracks between the additive and adhesive due to the physical or van der Waals force interactions between the packing and the binder, which provides a channel used to help the corrosion media reach the surface of the protected metal. Therefore, the corrosion resistance of common coating is reduced.

Throughout the history of the development of nano-composite coating, due to the full use of the nano-sized powder, significant changes have taken place in the paint industry. As titanium is the most corrosion-resistant metal in the marine environment, if nano-sized titanium powder is added as packing material to the anti-corrosion coatings, will it have the same effect as micrometre-grade titanium powder? This paper focuses on the previous study of anti-corrosion properties of coatings modified with 200 mesh titanium powder and nano-sized titanium particles. . $^{3,4}$

\footnotetext{
"Corresponding author: Dr. Xiuzhi Zhang, Vice professor
} e-mail: xiuzhizhang@tyust.edu.cn

\section{Experimental}

\section{Preparation of samples}

Test specimens were coated UNS G10190 panels. The coating was a commercially available epoxy resin (E20) modified with coal tar. As a curing agent, polyamine (650\#) was used. Powdered titanium (200 mesh) was added to the coating at room temperature in mass fractions $2 \%$ (numbers T1), $5 \%$ (numbers T2), $10 \%$ (numbers T3), $20 \%$ (numbers T4), and the nano-sized titanium powder $(50-120 \mathrm{~nm})$ mass fraction was 0 (numbers $0 \%$ nano), $5 \%$ (numbers $5 \%$ nano), $10 \%$ (numbers $10 \%$ nano), $20 \%$ (numbers $20 \%$ nano) respectively. 3

The panels were cleaned with analytical grade ethanol to remove water and degreased with analytical grade acetone before coating. After stirring thoroughly, the coating was applied to the metal by a model XB-120 coater made by Shanghai Xiandai Environment Engineering Technique Co. Ltd. Curing was carried out at room temperature and, after solidification, the specimens were kept in a desiccator for one week before being tested.

\section{Salt spray test}

According to ASTM B117, ${ }^{5}$ the corrosion resistance of samples prepared as described above was tested by the salt spray test for $2000 \mathrm{~h}$. 


\section{EIS inspections}

The experimental apparatus for the EIS investigation consisted of a Perspex ${ }^{\circledR}$ cylinder attached to the surface of the coated panel via an O-ring made of rubber in order to create a vessel to hold the electrolyte. ${ }^{6}$ The coated panel was the working electrode of electrolytic cell. A saturated $\mathrm{Ag} / \mathrm{AgCl}$ electrode was used as reference electrode and a platinum foil was used as counter electrode. All EIS experiments were performed at room temperature in aqueous solution with $w=3.5 \%$ of sodium chloride prepared by dissolving analytical grade sodium chloride in distilled water. Experimental tests were carried out by using an EG\&G model 273 Potentiostat/Galvanostat connected to a model 5210 Lock in Amplifier and controlled by a computer. Usually, five points were measured for each decade of frequency ranging from $10^{5} \mathrm{~Hz}$ to $10^{-2} \mathrm{~Hz}$. The amplitude of the superimposed potential was $20 \mathrm{mV}$. EIS measurements were carried out after $0.5 \mathrm{~h}$ firstly, and then once a day. After the EIS experiments, data were analysed by using Zview software.

\section{X-ray photoelectron spectroscopy (XPS) inspection}

XPS testing of the coating of UNS G10190 steel was performed by using the source of magnesium.

\section{Results and discussion}

The salt spray test results of coatings modified by 200 meshes titanium powder in mass fractions $2 \%$ (T1), $5 \%$ (T2), $10 \%$ (T3), $20 \%$ (T4), and coatings modified by nano-titanium powder $(50-120 \mathrm{~nm})$ in mass fractions 0 (0 \% nano), $5 \%$ (5 \% nano), $10 \%$ (10\% nano), $20 \%$ (20\% nano), are shown in Table 1. Clearly visible is the displacement of evenly small bubbles and emerged rust on the coating unmodified with titanium powder, indicating that the coating has been broken down and the steel matrix has been corroded at the point of emerged rust. On the other hand, there are cracks on the coatings modified with 200 mesh titanium. The coatings are more brittle than those without titanium. Therefore, the protective property is low. However, compared with the coatings mentioned above, there is no cracking but only local blistering appeared on the coatings modified with nano-sized titanium powder $(50-120 \mathrm{~nm})$ in mass fractions $5 \%$ (5 \% nano), $10 \%$ (10\% nano), and $20 \%$ (20\% nano). Consequently, the property of the coatings with nano-sized titanium powder is better than that of coating without titanium. The reason is that after adding nano-sized titanium powders, labyrinthic effects are enhanced because of the dispersion and distribution of nano-particles. On the other hand, there probably is some bonding between titanium nano-particles and epoxy modified by coal tar in the process of solidification. Therefore, the defects caused by titanium particles are decreased and the barrier property is promoted.
Ta b I e $1 \quad \begin{gathered}\text { - Results of coatings after } 2300 \text { hours of salt spray } \\ \text { testing }\end{gathered}$

Ta b I i c a 1 - Svojstva laka nakon 2300 sati ispitivanja raspršivanjem soli

\begin{tabular}{|c|c|c|c|}
\hline $\begin{array}{l}\text { Specimen } \\
\text { Uzorak }\end{array}$ & $\begin{array}{l}\text { Blistering } \\
\text { Mjehuranje }\end{array}$ & $\begin{array}{l}\text { Rust } \\
\text { Hrđa }\end{array}$ & $\begin{array}{l}\text { Cracking } \\
\text { Pucanje }\end{array}$ \\
\hline $0 \%$ nano-1 & - & $\begin{array}{c}\text { even } \\
\text { podjednako }\end{array}$ & - \\
\hline $0 \%$ nano- 2 & $\begin{array}{c}\text { evenly small blisters } \\
\text { podjednaki mali mjehuri }\end{array}$ & $\begin{array}{l}\text { some } \\
\text { ponegdje }\end{array}$ & - \\
\hline $0 \%$ nano-3 & $\begin{array}{c}\text { evenly small } \\
\text { podjednaki mali }\end{array}$ & $\begin{array}{l}\text { some } \\
\text { ponegdje }\end{array}$ & - \\
\hline $5 \%$ nano-1 & $\begin{array}{c}\text { evenly small } \\
\text { podjednaki mali }\end{array}$ & - & - \\
\hline $5 \%$ nano- 2 & $\begin{array}{c}\text { even } \\
\text { podjednaki }\end{array}$ & - & - \\
\hline $5 \%$ nano-3 & $\begin{array}{c}\text { even } \\
\text { podjednaki }\end{array}$ & - & - \\
\hline 10 \% nano-1 & $\begin{array}{l}\text { locally small } \\
\text { lokalni mali }\end{array}$ & - & - \\
\hline $10 \%$ nano- 2 & $\begin{array}{l}\text { locally small } \\
\text { lokalni mali }\end{array}$ & - & - \\
\hline $10 \%$ nano-3 & $\begin{array}{l}\text { large blister and stainless } \\
\text { metal substrate } \\
\text { veliki mjehur, netaknuta } \\
\text { podloga }\end{array}$ & - & - \\
\hline $20 \%$ nano- 1 & $\begin{array}{l}\text { large blister } \\
\text { veliki mjehur }\end{array}$ & $\begin{array}{l}\text { some } \\
\text { ponegdje }\end{array}$ & - \\
\hline $20 \%$ nano- 2 & $\begin{array}{l}\text { local } \\
\text { lokalno }\end{array}$ & - & - \\
\hline $20 \%$ nano-3 & $\begin{array}{l}\text { local } \\
\text { lokalno }\end{array}$ & - & - \\
\hline $\mathrm{T} 1-1$ & $\begin{array}{c}\text { even, large } \\
\text { podjednaki, veliki }\end{array}$ & - & - \\
\hline $\mathrm{T} 1-2$ & $\begin{array}{c}\text { even, small } \\
\text { podjednaki, mali }\end{array}$ & - & $\begin{array}{l}\text { local } \\
\text { lokalno }\end{array}$ \\
\hline $\mathrm{T} 1-3$ & $\begin{array}{l}\text { locally small } \\
\text { lokalni mali }\end{array}$ & - & - \\
\hline $\mathrm{T} 2-1$ & $\begin{array}{c}\text { evenly, small } \\
\text { podjednaki, mali }\end{array}$ & - & - \\
\hline T2-2 & $\begin{array}{c}\text { even, small, some large } \\
\text { podjednako, mali, neki veliki }\end{array}$ & - & - \\
\hline $\mathrm{T} 2-3$ & $\begin{array}{c}\text { even, small, some large } \\
\text { podjednako, mali, neki veliki }\end{array}$ & - & - \\
\hline T3-1 & $\begin{array}{l}\text { local } \\
\text { lokalno }\end{array}$ & - & $\begin{array}{l}\text { local } \\
\text { lokalno }\end{array}$ \\
\hline T3-2 & $\begin{array}{c}\text { evenly, small, some large } \\
\text { podjednako, mali, neki veliki }\end{array}$ & - & - \\
\hline T3-3 & $\begin{array}{l}\text { local } \\
\text { lokalno }\end{array}$ & - & $\begin{array}{l}\text { local } \\
\text { lokalno }\end{array}$ \\
\hline $\mathrm{T} 4-1$ & $\begin{array}{l}\text { local, small, some large } \\
\text { lokalno, mali, neki veliki }\end{array}$ & - & - \\
\hline T4-2 & - & - & $\begin{array}{l}\text { local } \\
\text { lokalno }\end{array}$ \\
\hline $\mathrm{T} 4-3$ & $\begin{array}{l}\text { locally small } \\
\text { lokalni mali }\end{array}$ & - & $\begin{array}{l}\text { local } \\
\text { lokalno }\end{array}$ \\
\hline
\end{tabular}

Ta ble 2 - Electrical resistance of coatings modified with micro-powder Ti after different immersion times Ta b I i c a 2 - Električni otpor lakova modificiranih mikroprahom titanija nakon različitog vremena uranjanja

\begin{tabular}{l|c|c|c|c}
\hline \multirow{2}{*}{$\begin{array}{l}\text { Immersion time } \\
\text { Vrijeme uranjanja }\end{array}$} & \multicolumn{4}{|c}{$\begin{array}{c}\text { Electrical resistance } / \Omega \\
\text { Električni otpor } / \Omega\end{array}$} \\
\cline { 2 - 5 } & $\mathrm{T} 1$ & $\mathrm{~T} 2$ & $\mathrm{~T} 3$ & $\mathrm{~T}$ \\
\hline 0.5 hour / 0,5 sati & $1.0529 \cdot 10^{10}$ & $5.8333 \cdot 10^{9}$ & $2.122 \cdot 10^{9}$ & $1.976 \cdot 10^{9}$ \\
192 hours / 192 sata & $2.6809 \cdot 10^{8}$ & $6.5716 \cdot 10^{8}$ & $9.7513 \cdot 10^{8}$ & $1.9618 \cdot 10^{9}$ \\
\hline
\end{tabular}


Ta b l e 3 - Electrical resistance of coatings modified with Ti nano-powder after different immersion times

Ta b I i c a 3 - Električni otpor lakova modificiranih nanoprahom titanija nakon različitog vremena uranjanja

\begin{tabular}{l|l|l|r|r}
\hline \multirow{2}{*}{$\begin{array}{l}\text { Immersion time } \\
\text { Vrijeme uranjanja }\end{array}$} & \multicolumn{4}{|c}{$\begin{array}{c}\text { Electrical resistance } / \Omega \\
\text { Električni otpor } / \Omega\end{array}$} \\
\cline { 2 - 5 } & $0 \%$ nano & $5 \%$ nano & $10 \%$ nano & $20 \%$ nano \\
\hline 0.5 hour / 0,5 sati & $4.98 \cdot 10^{7}$ & $6.212 \cdot 10^{8}$ & $1.078 \cdot 10^{10}$ & $1.159 \cdot 10^{10}$ \\
240 days / 240 dana & $1.161 \cdot 10^{8}$ & $4.3041 \cdot 10^{7}$ & $6.327 \cdot 10^{8}$ & $7.9014 \cdot 10^{7}$ \\
\hline
\end{tabular}

The EIS results indicated that within the scope of the study, the epoxy coal tar pitch coating modified with micro-powder Ti immersed in aqueous $3.5 \%$ sodium chloride solution, the resistance of coatings decreased with the increase in $\mathrm{Ti}$ content. Moreover, with prolonged immersion time, the order of electrical resistance changed. The resistance of coatings immersed for 192 hours increased with time. ${ }^{3}$ The EIS data for coatings immersed for different times are shown in Table 2.

However, by analysing the performance of coating with titanium nano-powder, it can be found that if immersed for half an hour, there is no regularity between the resistance of the coating and nano-sized titanium content. The electrical resistance of coating with $10 \%$ nano-sized $\mathrm{Ti}$ is similar to that of coating modified with $20 \%$ nano-sized titanium, and the coating without titanium has the minimum. ${ }^{4}$ Whereas, after a long immersion time when the resistance of the coatings is stable, the resistance of coating with $10 \%$ nano-sized titanium powder reaches the maximum, the order of electrical resistance of coating containing nano-powder titanium is different from that of coating containing 200 meshes titanium.

The results indicate that there is a difference between the order of electrical resistance versus nano-sized $\mathrm{Ti}$ and 200 meshes titanium content.

It is well known that the number of charge carriers in metal is far greater than that in organic coatings. As a result, because of the addition of the metal powder to organic coatings, the number of charge carriers in the coating containing metal powder should be increased. Moreover, the higher the amount of metal powder in the coating, the greater is the number of carriers.

Therefore, there is probably some chemical bonding during solidification, which makes the decreasing tendency caused by the increase in the number of charge carriers lower, and as a result of which the electrical resistance of coatings containing nano-titanium powder does not decrease with increased nano-titanium content.

In order to verify this view, the coating without titanium and coatings containing $10 \%$ nano-sized titanium powder were tested using XPS. From Fig. 1 it can be seen that the peak of $\mathrm{O}^{1 \mathrm{~s}}$ changed from $532.293 \mathrm{eV}$ (without Ti) to $532.719 \mathrm{eV}$ (for coating with $10 \%$ nano-sized Ti). Thus, it could be concluded that the mode of existence of oxygen in the coating had changed because of the addition of nano-sized titanium powder.

The infrared spectroscopy (IR) of unmodified coating and coating modified by $10 \%$ nano-sized titanium powder indi-

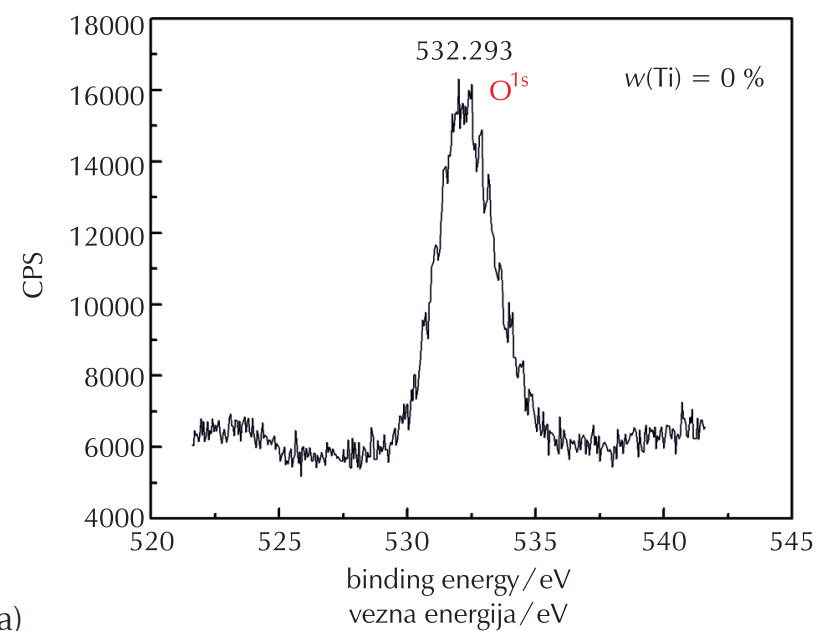

a)

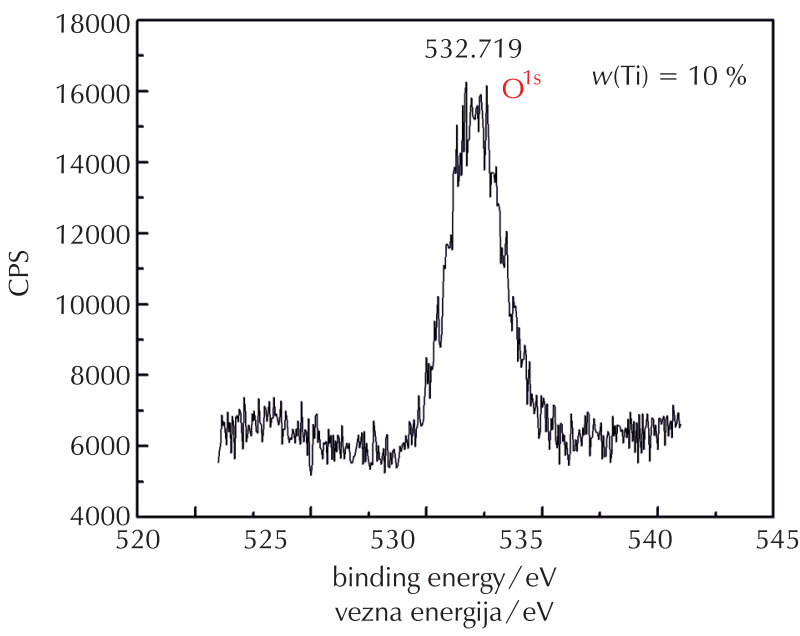

F i g . 1 - (a) XPS of the coal tar modified epoxy varnish coating; (b) XPS of the coal tar modified epoxy coating with 10 $\%$ nano-sized titanium

S I i k a 1 - (a) XPS epoksidnog laka modificiranog katranom kamenog ugljena; (b) - XPS XPS epoksidnog laka, modificiranog katranom kamenog ugljena, s $10 \%$ nanočestica titanija

cated that a fine distinction appeared at the low wave numbers and high wave numbers (Fig. 2). The peak of $551.30 \mathrm{~cm}^{-1}$ for coating without nano-sized titanium appears at wave number $556.27 \mathrm{~cm}^{-1}$ for coating with $10 \%$ nano-sized Ti powder. According to references, 7,8 there are peaks of $\mathrm{Ti}-\mathrm{O}$ at $638 \mathrm{~cm}^{-1}, 598 \mathrm{~cm}^{-1}$ and $558 \mathrm{~cm}^{-1}$. The offset of the peak at $551.30 \mathrm{~cm}^{-1}$ may be caused by $\mathrm{Ti}-\mathrm{O}$ bonding, while the bond $\mathrm{Ti}-\mathrm{O}$ might have been formed during the solidification. 


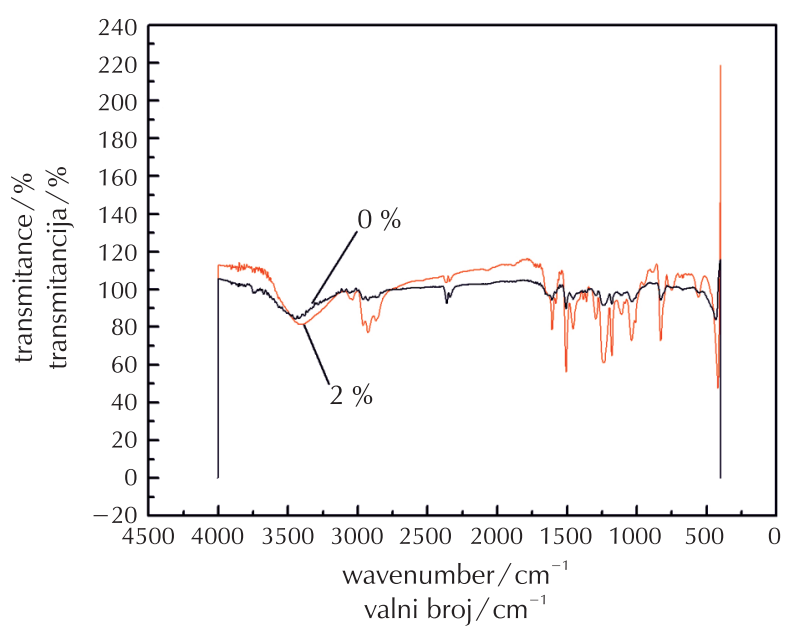

Fig. 2 - Infrared spectrum of the coal tar modified epoxy coatings without titanium and with $2 \%$ nano-sized titanium

SI i k a 2 - Infracrveni spektar epoksidnog laka, modificiranog katranom kamenog ugljena, bez dodataka is $2 \%$ nanočestica titanija

Based on the analysis mentioned above, the curing reaction of coatings modified by nano-sized titanium is deduced as follows. Here, formula (1) is the reaction that occurs when cured epoxy resin is cured with general amine, and formula (2) is the reaction that might have happened during solidification of coatings modified with nano-sized titanium powder.

From the equations, it can be seen that the titanium atom replaces the hydrogen atom of amidocyanogen and bonds with the active oxygen atom obtained by ring opening of epoxy group in the process of solidification. The reason is that with high surface energy, nano-sized powder titanium atoms are inclined to bond with the film forming matter around them to make the surface energy lower. In addition, as the II subgroup element, titanium atoms easily bond with oxygen atoms with electrons at $p$ atomic orbital and with unfilled $3 \mathrm{~d}$ energy band. So there is a $p$-d conjugative effect in the large molecular structure. Therefore, the bond energy is high. Many epoxy groups in epoxy resin are opened during the curing providing enough active oxygen atoms with electrons in $\mathrm{p}$ orbit to form $\mathrm{p}-\mathrm{d}$ conjugative effect. As a result, bonding formed between additive and film former matter. ${ }^{8}$

Equation (3) can be obtained through Eq. (2) - Eq. (1).

From a thermodynamic perspective, as the bond energy of $\mathrm{Ti}-\mathrm{O}$ and $\mathrm{H}-\mathrm{O}$ is $661.9 \mathrm{~kJ} \mathrm{~mol}^{-1}, 428.0 \mathrm{~kJ} \mathrm{~mol}^{-1}$, respectively, it could be concluded that the enthalpy of reaction (3), $\Delta_{\mathrm{r}} \mathrm{H}_{3}$, is approximately $-185 \mathrm{~kJ} \mathrm{~mol}^{-1}$, which is negative. According to references, ${ }^{9}$ when two high randomness substances are mixed, the mixed entropy change is very small, almost zero. Therefore, the Gibbs reaction energy of reaction (3) $\Delta_{\mathrm{r}} G_{3}$, at room temperature is below zero. Owing to the relationships among $\Delta_{\mathrm{r}} G_{1}, \Delta_{\mathrm{r}} G_{2}$, and $\Delta_{\mathrm{r}} G_{3}$ shown as Eq. (4) and Eq. (5) will be obtained.

$$
\begin{aligned}
& \Delta_{\mathrm{r}} G_{2}-\Delta_{\mathrm{r}} G_{1}=\Delta_{\mathrm{r}} G_{3} \\
& \Delta_{\mathrm{r}} G_{2}=\Delta_{\mathrm{r}} G_{3}+\Delta_{\mathrm{r}} G_{1}
\end{aligned}
$$

Here, $\Delta_{\mathrm{r}} \mathrm{G}_{3}<0, \Delta_{\mathrm{r}} \mathrm{G}_{1}<0$.

So,

$$
\Delta_{\mathrm{r}} \mathrm{G}_{2}<0 .
$$<smiles>CCCCCOCC(O)CNCC(C)CC(C)(CC(O)COCCCCC(C)(C)C)NC(C)C1OC1C1CO1</smiles><smiles>CCCCCOCC([O])C(N)OCC1CO1</smiles><smiles>CC(C)(C)CCCOCC(O)C(C)(C)NC1CO1</smiles>

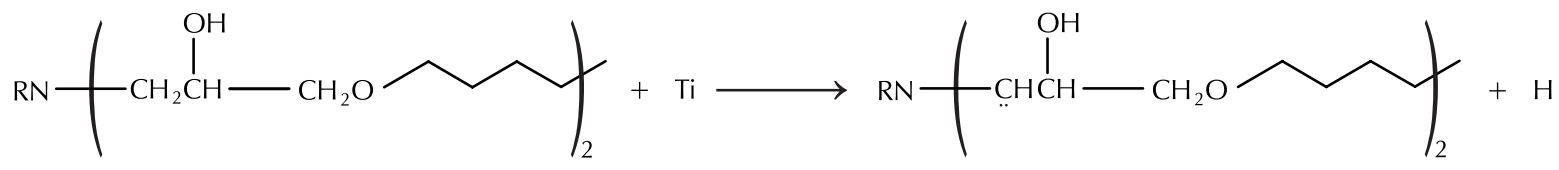


Therefore, it could be concluded that reaction (2) could have taken place during the curing of the coating. Thus, the nano-sized titanium powder added to the coating no longer exists in the form of a full machinery mixture. Due to the chemical key, a tight barrier layer is formed to prevent corrosive media such as water and oxygen from diffusing into the internal layer, which delays corrosion of the metal matrix. Moreover, thanks to the chemical key, the variation law for the resistance of the coating versus the increasing content of nano-sized titanium powder is different from that of coatings modified with 200 meshes titanium powder. In addition, due to this chemical bond, the toughness of the coating is not significantly different from lacquer coating.

\section{Conclusions}

Nano-titanium particles may be involved in the curing reaction of coatings. Therefore, the addition of titanium nano-sized powder did not significantly alter the physical properties of the coatings (toughness), and coatings modified with nano-sized titanium powder had better protection performance than the coatings with micrometre-sized titanium powder. Due to the chemical key between nano-sized titanium particles and the coating agent, the increase in the number of charge carriers in the coating due to the existence of the titanium metal is lower. For this reason, the resistance change order is different from the change law of the coating modified with the micrometre-sized titanium powder, and the change rule of the electrical resistance for the coatings modified with nano-sized titanium particles cannot be explained by the change of dielectric constants.

\section{ACKNOWLEDGEMENTS}

This paper was financially supported by science and technology innovation project for Institution of Higher Learning of Shanxi Province (No. 20081061).

\section{List of symbols and abbreviations Popis simbola i kratica}

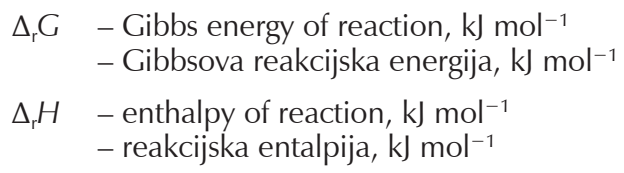

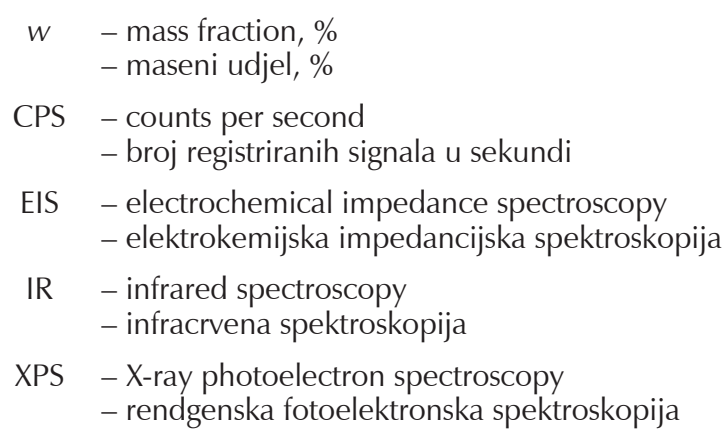

\section{References}

Literatura

1. S. X. Zhou, L. M. Wu, Investigation on the use of nanometric materials in coatings, China Paint. 4 (2001) 33-35.

2. Y. J. Chen, Q. M. Wei, J. B. Li, The prospect of advanced material science and applications, World Sci-tech R \& D 22 (2000) 57-60.

3. X. Z. Zhang, F. H. Wang, Y. L. Du, Protective performance of epoxy resin modified with coal tar coating studied by electrochemical impedance spectroscopy, Prog. Org. Coat. 53 (2005) 302-305, doi: http://dx.doi.org/10.1016/j.porgcoat.2005.03.010.

4. X. Z. Zhang, F. H. Wang, Y. L. Du, Effect of nano-sized titanium powder addition on corrosion performance of epoxy coatings, Surf. Coat. Technol. 201 (2007) 7241-7245, doi: http://dx. doi.org/10.1016/j.surfcoat.2007.01.042.

5. ASTM B117-03, Standard practice for operating salt spray apparatus, American Society for Testing of Materials, 2007.

6. C. N. Cao, J. Q. Zhang, Chapter 9, An Introduction to Electrochemical Impedance Spectroscopy, Science Press, Beijing, 2002, pp. 154-166.

7. A. Amirudin, D. Thierry, Application of electrochemical impedance spectroscopy to study the degradation of polymer-coated metals, Prog. Org. Coat. 26 (1995) 1-28, doi: http://dx. doi.org/10.1016/0300-9440(95)00581-1.

8. M. L. Sun, Chapter 2, Applied theory and technology of epoxy resin, China Machine Press, Beijing, 2002, pp. 18-48.

9. Q. Fu, R. N. Du, G. H Wang, Progress in polymer molecular composites, Polym. Mater. Sci. \& Eng. 15 (1999) 10-13. 


\title{
SAŽETAK
}

Utjecaj titanijevih nanočestica na antikorozivna svojstva epoksidnih lakova na čeliku

\author{
X. Z. Zhang* i Y. G. Li
}

Proučavana su zaštitna svojstva epoksidnih asfaltnih premaza s masenim udjelima titanijeva praha $2 \%, 5 \%, 10 \%$ i $20 \%$ te nanočestica titanija u masenim udjelima $0 \%, 5 \%, 10 \%$ i $20 \%$ elektrokemijskom impedancijskom spektroskopijom (EIS) i raspršivanjem soli. Strukture premaza proučavane su infracrvenom spektroskopijom i rendgenskom fotoelektronskom spektroskopijom (XPS).

Rezultati pokazuju da bi nanometarske čestice titanija mogle sudjelovati u učvršćivanju laka. Dodatak nanočestica titanija ne mijenja značajno fizička svojstva laka (žilavost). Lakovi s nanočesticama titanija bolje štite od lakova s mikrometarskim titanijevim prahom. Istodobno, zbog kemijskog međudjelovanja nanočestica titanija i laka, slabije je izraženo povećanje broja nosilaca naboja. Stoga ovisnost svojstava lakova o količini titanija nije jednaka u slučaju mikrometarskih ili nanometarskih čestica. Promjena električne otpornosti lakova modificiranih nanočesticama titanija ne može se objasniti promjenom dielektrične konstante.

Taiyuan University of Science \& Technology

Prispjelo 17. kolovoza 2013. Taiyuan 030024 Prihvaćeno 7. studenoga 2013.

Kina 